\title{
FUZZY LOGIC APPROACH FOR POST-MINING LAND USE PLANNING: A CASE STUDY ON COAL MINE OF PT. ADARO INDONESIA-SOUTH KALIMANTAN
}

\author{
PENDEKATAN FUZZY LOGIC UNTUK PERENCANAAN \\ PASCATAMBANG: STUDI KASUS PADA TAMBANG BATUBARA \\ PT. ADARO INDONESIA-KALIMANTAN SELATAN
}

\author{
MOHAMAD ANIS ${ }^{12, *}$, ARIFUDIN IDRUS ${ }^{2}$, HENDRA AMIJAYA ${ }^{2}$, and SUBAGYO ${ }^{3}$ \\ ${ }^{1}$ Directorate General of Mineral and Coal, \\ Ministry of Energy and Mineral Resources \\ Jalan Prof. Dr. Soepomo, SH, No. 10, Jakarta, 12870, Indonesia, \\ Ph. (+6221) 8295608 \\ e-mail:mochanis@yahoo.com \\ 2 Department of Geological Engineering \\ Gadjah Mada University, Yogyakarta, 55281 \\ ${ }^{3}$ Department of Mechanical and Industry Engineering \\ Gadjah Mada University, Yogyakarta, 55281.
}

\begin{abstract}
Currently coal companies, especially in South Kalimantan, have not yet been or only slightly entered the post-mining stage, although part of the mining blocks have been totally exploited, so that the company should have been preparing for the development of other sectors (non-mining). It shows that optimization of coal resources from exploration, mining to post-mining land use is necessary to ensure sustainable mining and sustainable development in terms of meeting the conservation aspect. To meet all aspects of conservation, the achievement of optimization in a series of mining business activities is started from the potential optimization of the coal remain resources until the optimization of post-mining land use is absolutely required. This research has analyzed several alternative sectors outside mining, which will be selected for optimization of utilization or post-mining land use, including plantation, recreation, industry and conservation sectors. The analyzing process used several parameters to assess the selected sectors including rainfall, slope and land use. Therefore, this study uses an approach of GIS-based methods (knowledge-driven), mainly fuzzy logic for post-mining land use planning. The selected mining area for this study belongs to PT. Adaro Indonesia company that has a Work Agreement for Coal Mining Exploitation. The result shows the suitability of plantation for the optimization of land use in all mining sites and also for conservation areas or protected forests.
\end{abstract}

Keywords: optimization, land use, post-mining, fuzzy logic

\begin{abstract}
ABSTRAK
Saat ini banyak perusahaan batubara terutama di Kalimantan Selatan belum ada atau hanya sedikit yang memasuki tahap pascatambang, walaupun sebagian blok tambang telah selesai dieksploitasi, sehingga perusahaan tersebut seharusnya sudah mempersiapkan pengembangan sektor lainnya (di luar sektor pertambangan). Hal tersebut menunjukkan tingkat optimalisasi sumber daya batubara mulai dari eksplorasi, penambangan sampai dengan pemanfaatan lahan pascatambang mutlak diperlukan untuk menjamin pertambangan berkelanjutan dan pembangunan berkelanjutan dalam memenuhi aspek konservasi. Jadi, pencapaian optimalisasi dalam suatu rangkaian kegiatan usaha pertambangan adalah mulai dari optimalisasi potensi sumber daya sisa batubara sampai dengan optimalisasi pemanfaatan lahan pascatambang mutlak dilakukan untuk memenuhi segala aspek konservasi. Penelitian ini telah menganalisis beberapa sektor alternatif di luar pertambangan yang akan dipilih untuk optimalisasi
\end{abstract}


pemanfaatan atau penggunaan lahan pascatambang, termasuk sektor perkebunan, rekreasi, industri dan konservasi. Studi ini menggunakan beberapa parameter untuk menilai sektor yang akan dipilih meliputi faktor curah hujan, kemiringan dan penggunaan lahan. Sehubungan dengan hal ini digunakan pendekatan metode berbasis GIS terutama logika fuzzy untuk perencanaan penggunaan lahan pascatambang. Wilayah pertambangan yang dipilih untuk penelitian ini adalah milik PT. Adaro Indonesia, sebagai pemegang izin Perjanjian Karya Pengusahaan Pertambangan Batubara. Hasilnya menunjukkan kesesuaian perkebunan untuk optimalisasi penggunaan lahan di semua lokasi pertambangan dan juga sebagian kecil lahan untuk kawasan konservasi atau hutan lindung.

Kata kunci: optimalisasi, penggunaan lahan, pascatambang, fuzzy logic

\section{INTRODUCTION}

The management capability in optimizing coal resources, will ultimately influence the success of sustainable mining and sustainable development. One of these successes is that a company has considered factors for determining the purpose or direction of designation after reclamation (Wang and Zhang, 2008; Wang, Liu and Xu, 2008; Luppens et al., 2009; Liu, Ye and Qi, 2012; Hao et al., 2013). Therefore, it can be determined the steps of environmental management and monitoring activities in achieving the reclamation success after postmining stage. This is also adapted to the socio-economic conditions of the communities surrounding coal companies in general that depend on the plantation and agriculture sectors based on a review of data from Central Bureau of Statistics (Badan Pusat Statistik, 2014). It also encourages mining companies to give priority of the land use for the plantation area, which is the development of optimization modelling to illustrate the above series whose estuary, that is a series of conservation policies (Wang and Zhang, 2008; Wang, Liu and $\mathrm{Xu}, 2008$; Luppens et al., 2009; Liu, Ye and Qi, 2012; Hao et al., 2013).

The success of reclamation is very supportive to determine the allotment of-post-mining land in accordance with the needs of the surrounding community of mining activities. While the success of the company in preparing communities around the mine, socially and economically contributes to the independence of the community.

Setiabudi and Hutamadi (2003) stated that the Conservation of Minerals Materials (COMM) is essentially a safeguard, repair and use of mined materials wisely that can provide high economic and social benefits, preserve the function of the environment, and ensure the sustainability of development for the community.

Optimization of land use related to the achievement of sustainable development is indicated by the level of reduction of dependence on the mining sector and the development of other sectors for the growth of new economic areas in post-mining land. The development of sectors outside the mine can be evaluated with common parameters such as land use, slope and rainfall that can influence the sustainable development with reference to the recommended parameters of previous studies.

This study analyzes the suitability of land for land use optimization and also by considering used several parameters to assess, which a sector will be selected, including rainfall, slope and land use factors (Watson, 2002; Craynon, 2011; Sharma, 2011). This study is limited in the analysis of optimization of conformity or land use using several criteria. Some of the main criteria comprise such as rainfall, slope and limits of land administration/infrastructure. In this analysis, it must first determine the output, because this study aims to optimize the mining area for sectors outside mining activities or sustainable development, then the output selected according to related statistics in the area of plantation, recreation, industry and conservation.

Fuzzy logic method has been widely used to assist in decision-making process. Fuzzy set was first developed in 1965 by Prof. Lotfi A. Zadeh. This theory has been widely developed and applied in various real problems. This method often begins with and developed based on a number of rules defined by decision makers (Lotfi et al., 1974 in Nugroho and Hartati, 2012). 


\section{METHODOLOGY}

This study developed a model for the determination of land suitability (plantation, industry, conservation/ protected forest, and recreational land) using the above-described theories of fuzzy logic. The object of this research took a case study at several coal companies that had mining licenses of Work Agreement for Coal Mining Exploitation (or abbreviated as PKP2B in Bahasa) in South Kalimantan.

Several coal mining companies included in PKP2B (Contract of Work) are still active in South Kalimantan (about 14 companies), in which PT. Adaro Indonesia was selected for this study. The company site is located in Balangan and Tabalong Regencies, South Kalimantan The site is approximately 220 $\mathrm{km}$ from Banjarmasin to the north and it can be reached by 6 -hour road trip. While the location of crushing plant and the port of loading is in the Kelanis Village, South Barito Regency, Central Kalimantan (Figure
1). The total area of this company is $35,800.80$ hectares (Directorate General of Mineral and Coal, 2014).

The analysis method is a combination of geographic information system (GIS) and fuzzylogic analysis methods, which has been applied to test all research related factors. The purpose of the analysis can be described simultaneously with the stages of the main analysis method, which is the GIS modelling analysis method. The results of the expected analysis are for land development or post-mining land optimization in the framework of sustainable development. The same thing can be determined by overlaying maps approaches related to the optimization of land use. Surely, it must first set the initial criteria for the optimization of land suitability (fuzzy logic). This study uses Arc-gis 10.2 software with added fuzzy logic packages that have been available, including as a fuzzy logic calculation tool.

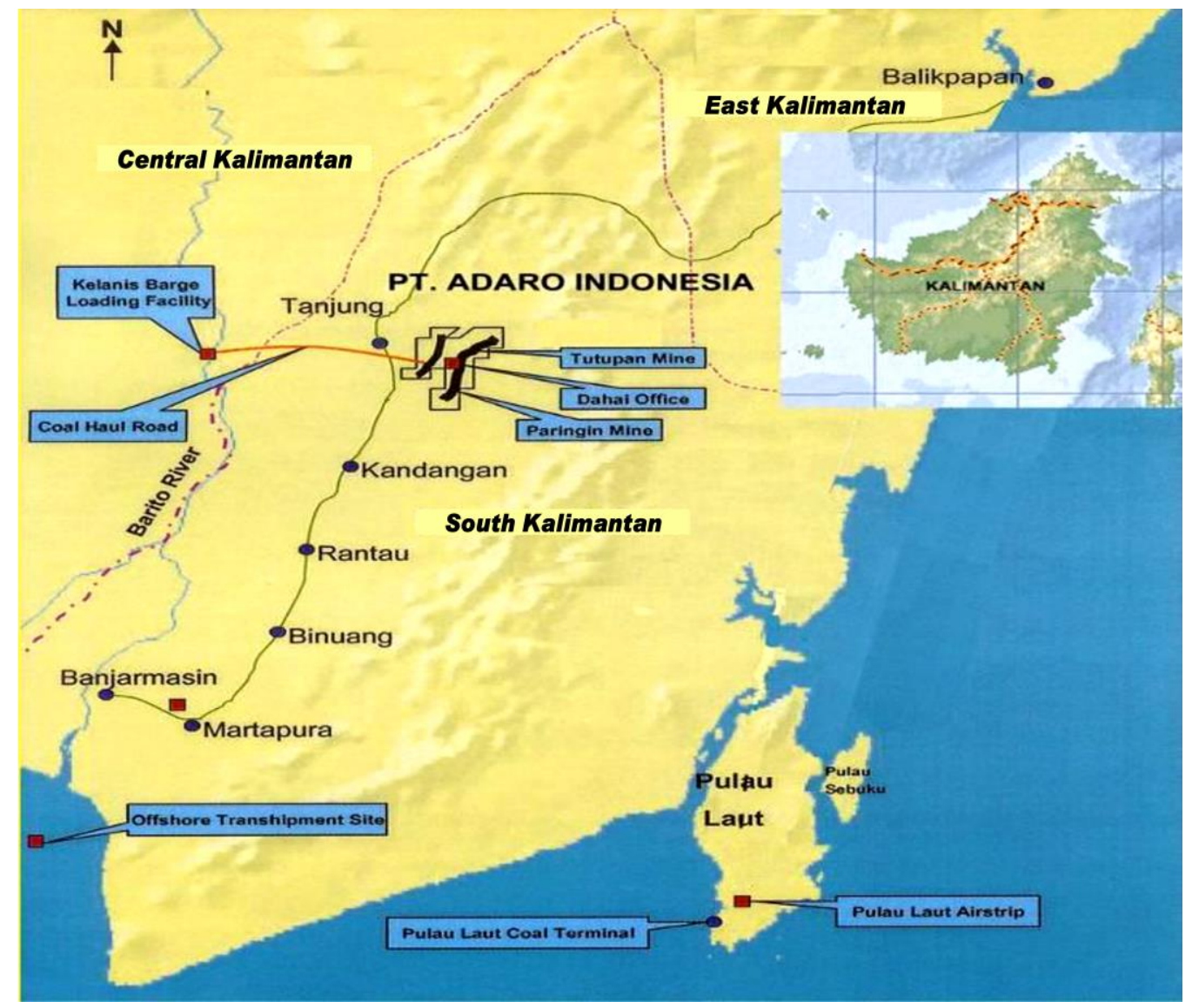

Figure 1. Location of PT Adaro Indonesia in South and Central Kalimantan 
Analysis of land suitability for post-mining land use optimization is carried out through a series of fuzzy logic analyzes. This study uses the help of Mat lab software to solve complex calculations of the related graphical methodology. The system fuzzy logic analysis also represents a series of three important steps: fuzzification, inference and defuzzification (Cordón et al., 2001 in Foroutan and Delavar, 2012) as illustrated in Figure 2. The fuzzification stage is the stages performed to change the firm or crisp/bivalent values into the values of the more specific natural fuzzy membership (fuzzification) for all inputs using Mat lab software.

Optimization of the suitability of land/land use in this study is directed to the use of plantation/agricultural and conservation areas, whereas the determination of the criteria optimization of land use can be seen in Table 1. The criteria in the table refers to the rules that set by the government and refers to the Guidelines for the Spatial Layout (RTRW) of the Regency (Law No. 26 Year 2007 on Spatial Planning) Such the law was issued by the National Spatial Planning Coordinating Agency of the Republic of Indonesia (Nugroho and Hartati, 2012).

The criteria and sub-criteria determination of land use calculation must be referred to the above laws, so that it cannot be done arbitrarily (Nugroho and Hartati, 2012). In this case, to make the determination of fuzzy logic calculation criteria was used the criteria and sub-criteria of land suitability determination that include:
- availability of water (rainfall, humidity, drainage, surface area of aquifer);

- availability of oxygen (drainage, slope);

- landscape/morphology (physiographic, slope inclination, erosion sensitivity, erosion rate);

- type of vegetation (forest, rice field);

- road network (primary, secondary).

In detail, the above criteria for land types cover plantation, conservation, recreation and industry landscape considers the fulfillment of criteria with the characteristics shown in Table 1.

Analysis of land suitability for post-mining land use optimization was conducted through a system of fuzzy logic. This research used a Mat lab software to solve a complex calculation of fuzzyfication from related graphical method. The analysis of fuzzyfication deals with the necessary steps to convert bivalent values into specific membership values (Nugroho and Hartati, 2012).

Triangular membership functions actually have some other membership functions, such as GenBell, Sigmoid, Phi, Trapezoidal, Gaussian, Piece Wise Linear, and so on. This study uses Triangle membership function in this analysis. Thus, the formula for calculating the degree of membership used is as follows (Nugroho and Hartati, 2012):

$$
\begin{gathered}
\mu-\text { triangular } \\
(x, a, b, c)
\end{gathered}\left[\begin{array}{c}
0, x<a, x>c \\
(x-a) /(b-a), a<x<b \\
-(x-c) /(c-b), b<x<c
\end{array}\right.
$$

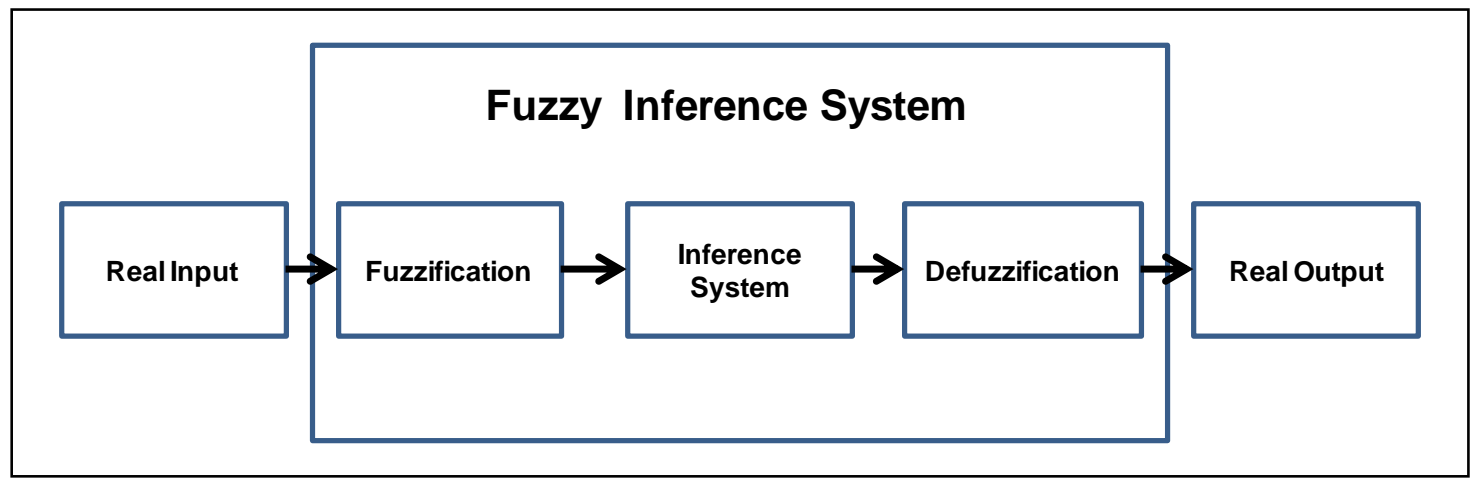

Figure 2. The scheme of the analysis fuzzy logic system 
Table 1. The criteria of optimal value for the selection of four land use alternatives

\begin{tabular}{l}
\hline \multicolumn{1}{c}{ Criteria } \\
\cline { 2 - 3 } \\
\cline { 2 - 3 } Slope \\
$0-8 \%$ \\
$8-15 \%$ \\
$15-25 \%$ \\
$25-45 \%$ \\
$>45 \%$ \\
Rain Fall \\
$0-100 \mathrm{~mm}$ \\
$100-200 \mathrm{~mm}$ \\
$200-300 \mathrm{~mm}$ \\
$300->600 \mathrm{~mm}$ \\
Distance to Road \\
$1-3 \mathrm{~km}$ \\
$3-5 \mathrm{~km}$ \\
$>5 \mathrm{~km}$ \\
Distance to Settlement \\
$1-3 \mathrm{~km}$ \\
$3-5 \mathrm{~km}$ \\
$>5 \mathrm{~km}$ \\
Distance to River \\
$1-3 \mathrm{~km}$ \\
$3-5 \mathrm{~km}$ \\
$>5 \mathrm{~km}$
\end{tabular}

\section{RESULTS AND DISCUSSION}

The analysis of the land suitability for the land use is the basis of the environmental management of the coal company. As described in the previous chapter, fuzzy logic analysis includes three important steps, namely, inference and defuzzification. In this research, the series of analysis can be applied to the company that has PKP2B licence through three stages of fuzzy logic analysis. The first stage is fuzzification that perform to changing the firm or crisp/bivalent values into the values of the more specific natural fuzzy membership (fuzzification) for all inputs using the Mat lab software (Figure 3). Determination the most optimal output (land suitability) used several criteria such as:

- tilt slope with a certain class distance;

- rainfall at certain periods with reference intervals accordingly;

- administrative map in the form of the distance from the highway;

- administrative map in the form of the distance from settlement e.g. village;

- administrative map in the form of the distance from the parent river.

This criterion refers to the rules that have been regulated by the government and refers to the Guidelines for Spatial Layout (RTRW) of the Regency (Law No. 26 Year 2007 on Spatial Planning) issued by the National Spatial Planning Coordinating Agency of the Republic of Indonesia (Nugroho and Hartati, 2012). The above criteria parameters must be generally inputted without a specific limitation according to the class distance and determined by reference or field research data, e.g. drought slope and rainfall map. The result of this series of analysis stages is shown in Figure 3.

After completing related main criteria inputs, the next step is the fuzzy set inference rules (Nugroho and Hartati, 2012). Based on the reference guide of rainfall map, slope and land administration/land use and related reference then arranged fuzzy inference rules according to predetermined output objectives. The process does not only take into consideration some of the detailed analyzed criteria, but in this research also select the suitable area for land optimization such as plantation land, conservation sites, recreational lands and industrial land. Those can be determined based on the overlay map land unit map by fuzzy logic determination method and GIS modeling approach. 
In conducting analysis of suitability optimization or land utility, this research uses criteria map. Some of the main criteria such as the rainfall map around concession of PT. Adaro Indonesia and the slope map give significant contribution for decision optimization of land suitability. Analysis of GIS modelling for suitability optimization uses the criteria above and guidance of reference (Figure 7) based on the criteria as follows:

- slope, in the research area is generally 0$25 \%$ for plantation and over $25 \%$ for conservation land;

- rainfall, generally over $100 \mathrm{~mm}$;

- distance from street, close enough around about $1 \mathrm{~km}$;

- distance from settlement, close enough about $1 \mathrm{~km}$;

- distance from river, close enough about $1 \mathrm{~km}$;

Referring to Nugroho and Hartati (2012), the determination of fuzzy logic above was based on land suitability optimization criteria. The inference process for this fuzzy logic method can manually be performed either by Mamdani or Sugeno methods. One example for this analysis is the rainfall criterion (Figure 4) with certain sub criteria such as high $(>100 \mathrm{~mm})$ and low rainfall $(<100 \mathrm{~mm})$. Application of the sample analysis, this research used the Mamdani model (Nugroho and Hartati, 2012) as follows:

- If Rain_Fall Is Low Or Medium THEN Characteristic _Land Is Land_Recreation;

- If Rain_Fall Is High Or Very high THEN Characteristic Land Land_Conservation;

- If Rain Fall IS Low THEN Characteristics_Land IS Land_Industry;

- If Rain_Fall IS Low Or Medium Or High THEN Characteristic_Land Is Lahan_Plantation.

The next step of the fuzzy logic analysis or deffuzification stage is to return the results of the inference analysis to the firmly return value to determine the highest output value. The result of the above analysis at $\mathrm{PT}$. Adaro showed the limit criteria indicator after the defuzzification. The results of this analysis is shown in Figure 5 and 6.

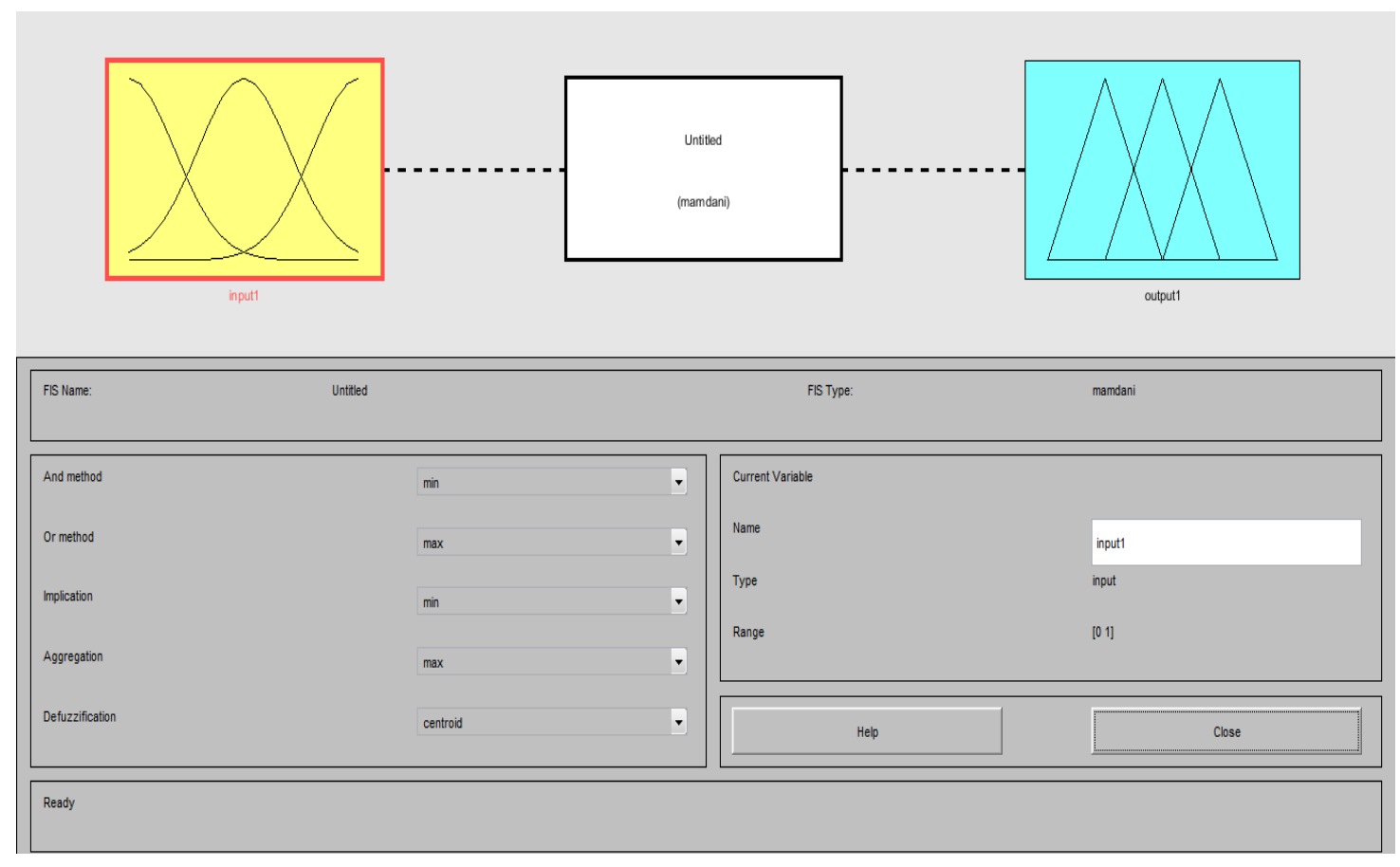

Figure 3. The fuzzification stages inputs all the criteria and output data 
Fuzzy Logic Approach for Post-Mining Land Use Palnning: A Case Study ... Mohamad Anis et al.

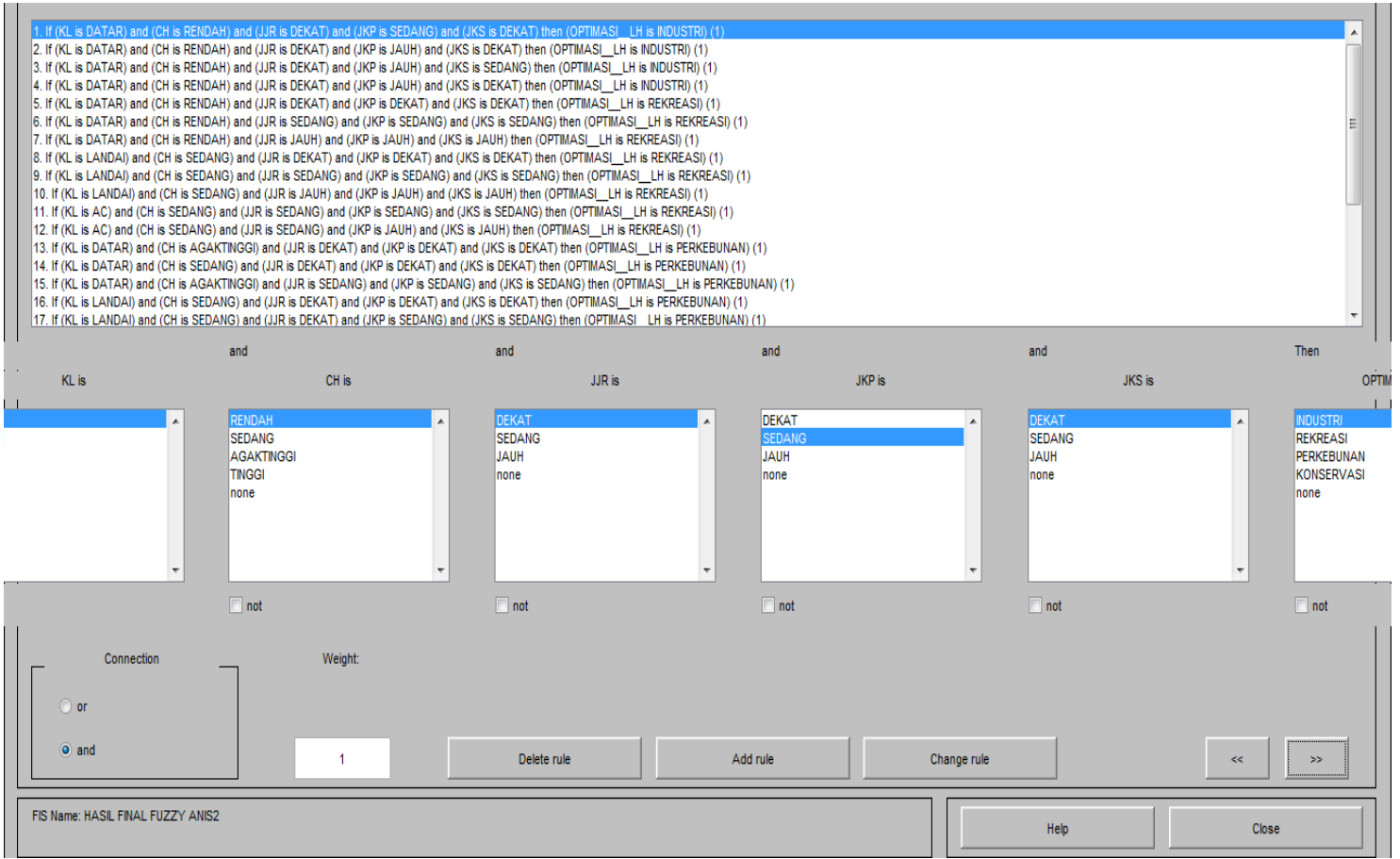

Figure 4. Input data in the form of rules

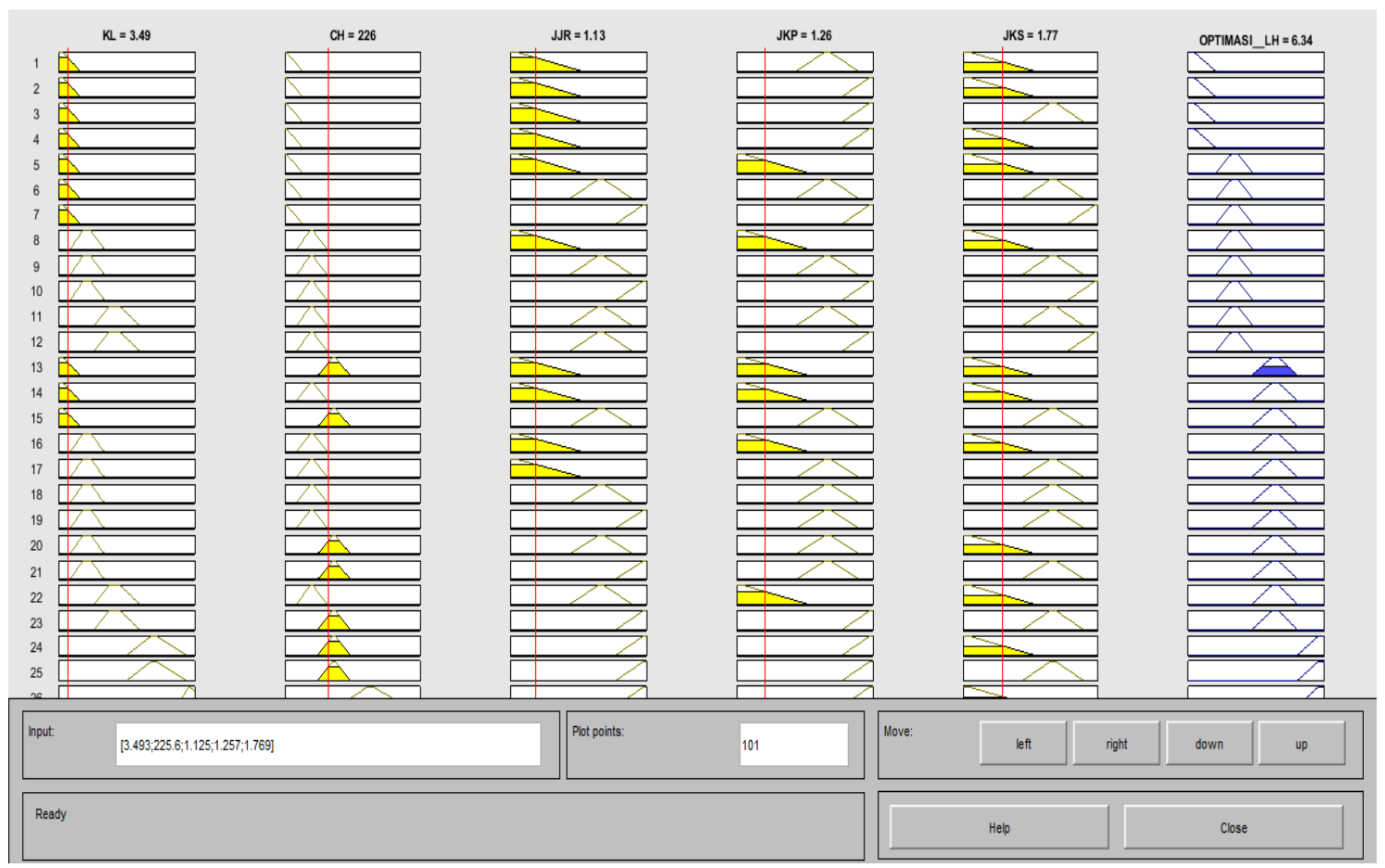

Figure 5. The process of defuzzification stage for plantation output 


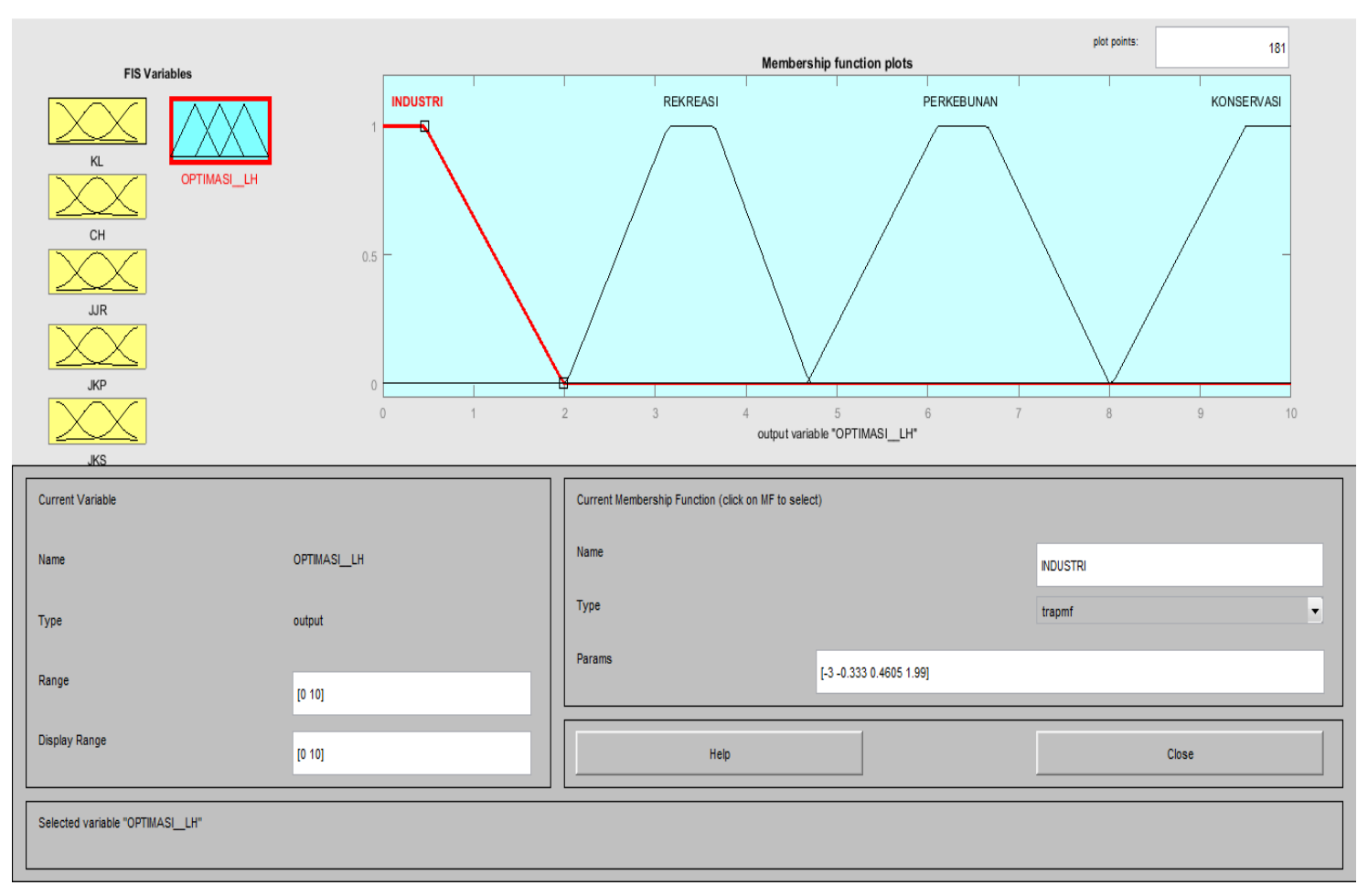

Figure 6. Results for the plantation output of the defuzzification process

After a series of fuzzy logic analyzes, simultaneous and integrated GIS analysis is overlaid using spatial operations and then converted into vector-based GIS databases, since the entire overlay process is completed in a vector format shapefile (Bonham-Carter, 1994). The stages are done by input data into fuzzy logic devices in GIS, including input criteria e.g. slope map, rainfall map, distance map from highway, distance map of settlement and distance map from river. This study also determines the optimization of post mining land with the selection of alternative land use conservation, plantation, recreation and industry) as output data.

The series of processes used the union function in ArcGIS 10.2 (Lotfi et al., 1974 in Nugroho and Hartati, 2012). The result can be seen that the role of the predictor map can produce the land unit map that must be re-analyzed by fuzzy logic analysis of course through several series of analysis process (Bonham-Carter, 1994).

The results of the analysis also show that the other allotment is the land use for conservation areas of only about $0.08 \%$ of the total concession area compared to the plantation area and about $1.46 \%$, which is not potential outside the two areas. The also show that the environmental performance has the potential impact directly to the environmental management performance of PT. Adaro Indonesia, which has long been in the operational stage of production (Suyartono, 2004; Craynon, 2011; Sharma, 2011).

This study has analyzed the potential of the plantations based on the local statistical data to contribute significantly beyond the mining sector. The analysis result shows that the prepared criteria suggest the optimum output of land to the plantation sector (Shields, 2007). It can be shown that the plantation sector contributes to the sustainable development data from Central Bureau of Statistics (Badan Pusat Statistik, 2014). Therefore, the data of the output criteria for the plantation sector should have been considered for preparing PT. Adaro Indonesia's future corporate reclamation plan (Suyartono, 2004; Craynon, 2011; Sharma, 2011).

Based on the local government statistic central data, the analysis of land suitability optimization in PT. Adaro is proposed since 
the post mining activity which is expected to be returned to the original function (rubber plantation area (Figure 7.). This is in accordance with the social need and encourage economic level in Tabalong and Balangan Regencies, where there has been rubber plantation processing plant. The result of this analysis shows that socialeconomic performance of the society is dominant enough data from Central Bureau of Statistics (Badan Pusat Statistik, 2014).

The analysis result also indicated that the environmental performance does not always affect directly because the performance of the processing surrounding PT. Adaro Indonesia is still in the early stage. The result of analysis suggested that PT. Adaro Indonesia should manage its environment (reclamation and revegetation) into the plantation sector such a sector will give a socio-economic advantage besides the mining sector (Shields, 2007).

The plantation sector will give a significant contribution to the sustainable development.
Therefore, the selected plantation sector should be considered to the post mining plan of PT. Adaro Indonesia (Figure 7). The company has also an area of approximately $97.7 \%$, which is feasible and significant to be diverted to other sectors outside mining activities in order to achieve complete sustainable development above (Figure 7).

\section{CONCLUSION}

The variables of land use are the important factor to determine the optimization of land use suitability within the framework of sustainable development, as shown below:

- result of GIS modeling integration approach (overlay) and fuzzy logic analysis shows that the land use is based on the employed criteria such as infrastructure map, rainfall and slope;

- the optimization of the suggested land is plantation area (about 97.7\%) or agriculture and the rest is conservation areas (about $0.08 \%$ ).

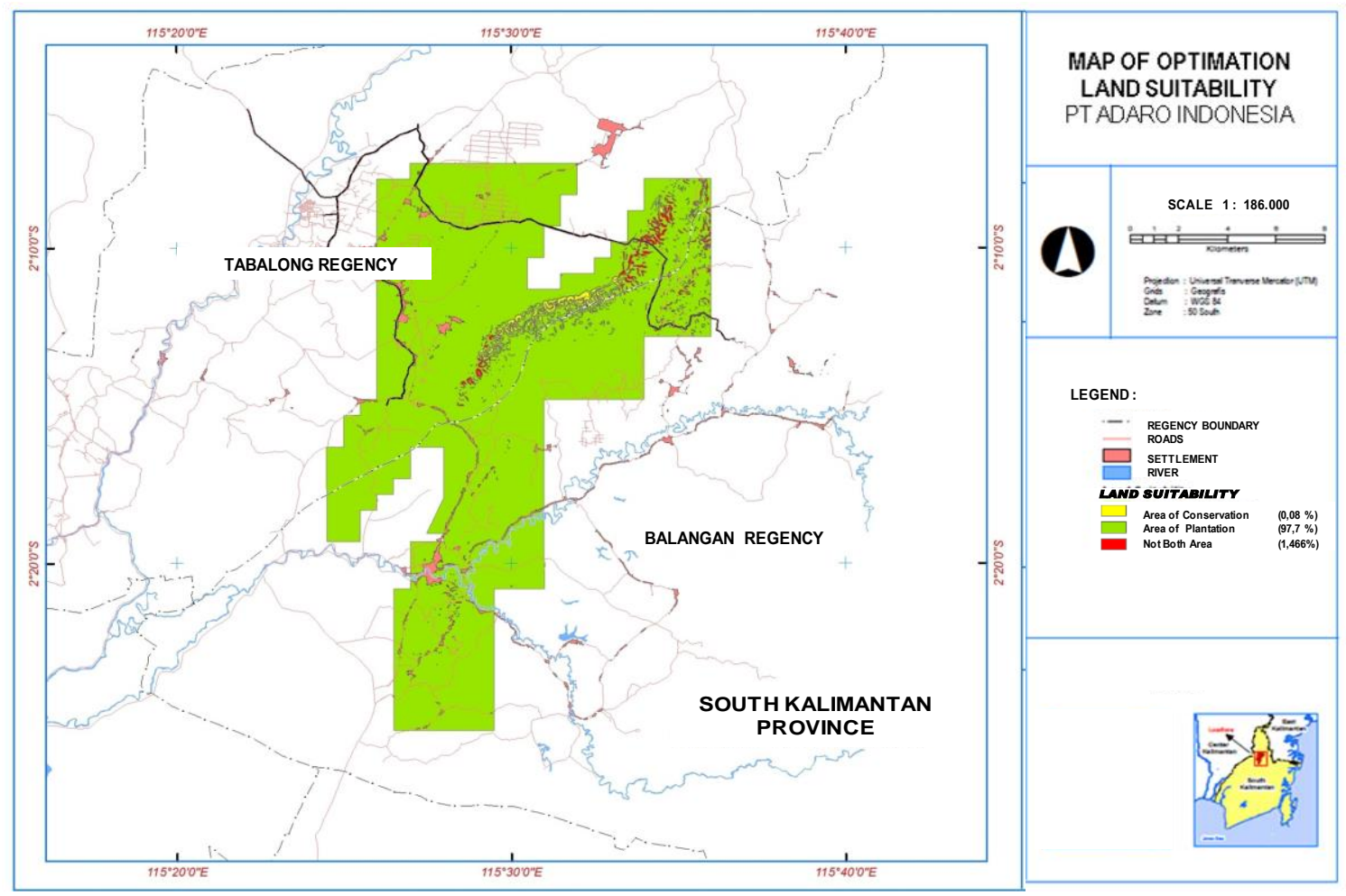

Figure 7. Map of optimization land suitability for post mining planning 


\section{ACKNOWLEDGEMENT}

The authors would like to acknowledge PT. Adaro Indonesia for the cooperation and providing data. The authors also appreciate the assistance of the Directorate General of Mineral and Coal for data collection and database creation.

\section{REFERENCES}

Badan Pusat Statistik (2014) Kabupaten Balangan dan Tabalong dalam angka 2014. Paringin.

Bonham-Carter, G. F. (1994) "Modelling with GIS," in Geographic information systems for geoscientists. 1st Editio. Pergamon, p. 416. Available at: https://www.elsevier.com/books/geograp hic-information-systems-forgeoscientists/bonham-carter/978-0-08041867-4.

Craynon, J. R. (2011) Approaches and barriers to incorporating sustainable development into coal mine design. Virginia Polytechnic Institute. Available at: https://vtechworks.lib.vt.edu/bitstream/ha ndle/10919/29660/Craynon_JR_D_2011 .pdf?sequence $=1$ \&isAllowed $=y$.

Directorate General of Mineral and Coal (2014) Dokumen kegiatan tahunan (RKAB dan RKTTL) perusahaan PKP2B di Prov. Kalimantan Selatan. Jakarta.

Foroutan, E. and Delavar, M. (2012) "Urban growth modeling using fuzzy logic," in Annual Conference Sacramento California. New York: American Society for Photogrammetry \& Remote Sensing, pp. 154-163. Available at: https://www.asprs.org/conferenceproceedings/sacramento-2012-asprsannual-conference-proceedings.html.

Hao, Y., Wu, Y., Zhang, S. and Chen, L. (2013) "Integrated Evaluation of Ecological Sustainability of a Mining Area in the Western Region of China," International Journal of Environmental Science and Development, 4(2), pp. 196-201. doi: 10.7763/IJESD.2013.V4.334.

Liu, H., Ye, C. and Qi, X. (2012) "Study on developing coal resource with the socialeconomic influence in Erdos City," Cross-Cultural Communication, 8(6), pp. 112-117. doi: 10.3968/j.ccc.1923670020120806.2415.
Luppens, J. A., Rohrbacher, T. J., Osmonson, L. M. and Carter, M. D. (2009) Coal resource availability, recoverability, and economic evaluations in the United States-A Summary, The National Coal Resource Assessment Overview. Denver, Colorado. Available at: https://pubs.usgs.gov/pp/1625f/downloa ds/ChapterD.pdf.

Nugroho, A. and Hartati, S. (2012) "Sistem pendukung keputusan berbasis logika fuzzy untuk penentuan kesesuaian penggunaan lahan (Studi kasus: Kabupaten Semarang)," Jurnal Aristoteles, 9(2), pp. 1-14.

Setiabudi, B. T. and Hutamadi, R. (2003) "Kebijakan konservasi bahan galian dalam pengelolaan sumberdaya mineral di Indonesia," in Kolokium Hasil Kegiatan Inventarisasi Sumberdaya Mineral-DIM. Bandung: Pusat Sumber Daya Geologi, p. 5.1-5.10. Available at: http://psdg.bgl.esdm.go.id/kolokium 2003/konservasi/Proc KEBIJAKANBambang.pdf.

Sharma, P. D. (2011) Bringing sustainability in coal mining operations is need-of-thehour, www.issuu.com. Available at: https://issuu.com/sharmapd1/docs/bringi ng_sustainability_in_coal_mining_operat ions (Accessed: August 10, 2017).

Shields, D. J. (2007) "The contributions of geologic information to economic, social, and environmental sustainability," in Proceedings for a Workshop on Deposit Modeling, Mineral Resource Assessment, and Their Role in Sustainable Development. Reston, Virginia: U.S. Geological Survey Circular 1294, pp. 17-18. Available at: https://pubs.usgs.gov/circ/2007/1294/rep orts/paper2.pdf.

Suyartono (2004) Good mining practices: Konsep tentang pengelolaan pertambangan yang baik dan benar. Semarang: Studi Nusa.

Wang, X. and Zhang, G. (2008) "Study on the sustainable development of Henan coal industry under the guide of circular economy," in International Conference on Management Science and Engineering. ST.PLUM-BLOSSOM PRESS PTY.LTD., pp. 659-663. Available at: http://www.seiofbluemountain.com/uploa d/product/200910/2008glhy07a7.pdf. 
Fuzzy Logic Approach for Post-Mining Land Use Palnning: A Case Study ... Mohamad Anis et al.

Wang, Z., Liu, Y. and Xu, Y. (2008) "The problems in sustainable development of resource orientated city and countermeasures," International Journal of Business and Management, 3(6), pp. 128-131. doi: 10.5539/ijbm.v3n6p128.
Watson, W. D. (2002) "GIS assessment of remaining coal resources with high market potential," in 2002 Conference Proceedings ESRI. San Diego, CA $2002 . \quad$ Available at: https://library.esri.com/docs/proc02/pap1 147/p1147.htm. 
